\title{
Analiza fazowa strefy granicznej połączenia stopu Hastelloy X z lutem Palnicro 36M
}

\author{
Phase analysis of phase boundary zone \\ for Hastelloy X with Palnicro 36M brazed joint
}

\section{Streszczenie}

W artykule scharakteryzowano strefę graniczną połączenia Hastelloy X - Palnicro $36 \mathrm{M}$, w której oddziaływały bezpośrednio ciekły lut z materiałem podłoża w stanie stałym. Głównym celem prowadzonych badań była analiza mikrostruktury strefy granicznej oraz identyfikacja występujących w niej faz. W badaniach wykorzystano mikroskopie świetlną, skaningową mikroskopie elektronową (SEM) wraz z analizą EDS oraz metodę dyfrakcji rentgenowskiej (XRD).

W strefie granicznej zidentyfikowano fazy tworzone przez: molibden nikiel $\left(\mathrm{Mo}_{1,08} \mathrm{Ni}_{2,92}\right)$, tetrataenite NiFe, chrom nikiel (CrNi), bor chrom $\mathrm{Cr}_{5} \mathrm{~B}_{3}$. Badania wskazały również na możliwość występowania w strefie granicznej faz na bazie związków międzymetalicznych $\mathrm{Cr}_{3} \mathrm{NiB}_{6} \mathrm{i} \mathrm{Mo}_{6}\left(\mathrm{Ni}_{0,75} \mathrm{Si}_{0,25}\right)_{7}$.

Słowa kluczowe: lutowanie twarde; lut Palnicro 36M; dyfrakcja rentgenowska

\begin{abstract}
The article describes boundary zone for the Hastelloy $X$ - Palnicro 36M brazed joint, in which liquid brazing filler metal interacted directly with solid base metal. The main objective of the research was to analyze the microstructure of the border zone and to recognize the occurring phases. Methods used in the research were light microscopy, scanning electron microscopy (SEM) with EDS analysis and X-ray diffraction (XRD).

In the phase boundary zone the following phases were identified: molybdenum nickel $\left(\mathrm{Mo}_{1.08} \mathrm{Ni}_{2.92}\right)$, tetrataenite $\mathrm{NiFe}$, chromium nickel ( $\mathrm{CrNi}$ ), boron chromium $\mathrm{Cr}_{5} \mathrm{~B}_{3}$. Studies have also indicated the possibility of occurrence of phases based on $\mathrm{Cr}_{3} \mathrm{NiB}_{6}$ and $\mathrm{Mo}_{6}\left(\mathrm{Ni}_{0.75} \mathrm{Si}_{0.25}\right)_{7}$ intermetallic compound in the phase boundary zone.
\end{abstract}

Keywords: brazing; brazing alloy Palnicro 36M; X-ray diffraction

\section{Wprowadzenie}

We współczesnych silnikach lotniczych istotną rolę odgrywają żaroodporne i żarowytrzymałe stopy na bazie niklu, tzw. superstopy. Jedną z metod spajania superstopów stosowanych w przemyśle lotniczym jest lutowanie twarde

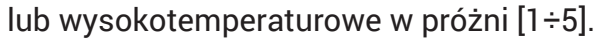

Do lutowania superstopów niklowych w przemyśle lotniczym często stosowane są luty na bazie niklu z serii BNi. Jednym z głównych przedstawicieli tej grupy stopów jest lut BNi-2, który oprócz Ni posiada dodatki Cr, Fe, B i Si. W silnikach lotniczych znajdują się również złącza wykonane przy użyciu Palnicro 36M, który jest lutem spoza serii BNi. W tym stopie głównym składnikiem jest Ni wraz z dodatkami Cr, B, Si i Pd. W stosunku do BNi-2 różni się on brakiem Fe oraz obecnością Pd - ok. 36\%. Skład chemiczny, a także temperaturę solidus, likwidus oraz zalecaną temperaturę luto-

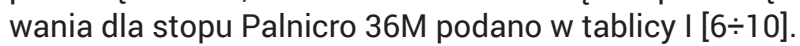

W połączeniu lutowanym na przykładzie pary materiałów Hastelloy X - Palnicro 36M można wyróżnić 3 podstawowe strefy: strefa wielofazowa, faza podstawowa i strefa graniczna, w której bezpośrednio oddziaływały ciekły lut i materiał podłoża. Strukturę połączenia z widocznymi 3 strefami przedstawiono na rysunku 1 (mikroskopia świetlna).

Dostępne są prace $[11 \div 14]$, w których analizie poddano strukturę złączy lutu Ni-Cr-Pd ze stalami nierdzewnymi i superstopami niklu z grupy Inconel. W niniejszej pracy skupiono się na bardzo wąskiej strefie, gdzie bezpośrednio oddziaływały ciekły lut z podłożem w stanie stałym (strefa graniczna). Przeprowadzone badania miały na celu określenie składu fazowego granicznej strefy lut - podłoże.

Tablica I. Skład chemiczny lutu Palnicro 36M, \% wag. [9] Table I. Chemical composition of Palnicro 36M, wt.\% [9]

\begin{tabular}{|c|c|c|c|c|}
\hline Pd & Ni & Cr & Si & B \\
\hline 35,6 & Bal. & 10,5 & 0,5 & 3,0 \\
\hline \multicolumn{3}{|c|}{ Temperatura Solidus } & \multicolumn{2}{|c|}{$820^{\circ} \mathrm{C}$} \\
\hline \multicolumn{2}{|c|}{ Temperatura Likwidus } & \multicolumn{2}{|c|}{$960^{\circ} \mathrm{C}$} \\
\hline \multicolumn{2}{|c|}{ Zalecana temperatura lutowania } & $970 \div 1050{ }^{\circ} \mathrm{C}$ \\
\hline
\end{tabular}

Mgr inż. Michał Baranowski - Instytut Mechaniki Precyzyjnej, dr inż. Dorota Moszczyńska, inż. Tomasz Panasiuk - Politechnika Warszawska.

Autor korespondencyjny/Corresponding author: michal.baranowski@imp.edu.pl 


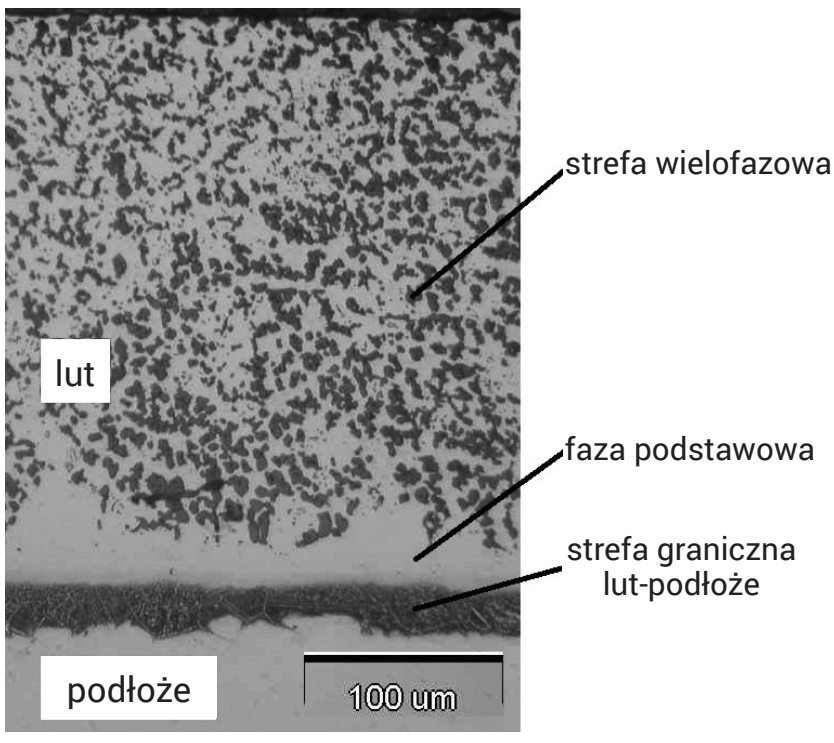

Rys. 1. Połączenie lutowane Hastelloy $X$ - Palnicro $36 \mathrm{M}$ Fig. 1. Hastelloy $X-$ Palnicro $36 \mathrm{M}$ brazed joint

\section{Materiały i eksperyment}

W pracy badaniom poddano połączenie powstałe w procesie lutowania w piecu próżniowym. Temperatura lutowania oraz czas wytrzymania w tej temperaturze wyniosły odpowiednio $995^{\circ} \mathrm{C}$ i 60 minut. W procesie lutowania zastosowano lut Palnicro $36 \mathrm{M}$ w postaci folii o grubości $0,05 \mathrm{~mm}$, którego skład chemiczny przedstawiono w tablicy I. Podłożem był superstop niklu Hastelloy X, w którego składzie brakuje pierwiastków odpowiedzialnych za wydzielenia $\gamma^{\prime}$ $\left(\mathrm{Ni}_{3}(\mathrm{AlTi})\right)$ i $\mathrm{y}^{\prime \prime}\left(\mathrm{Ni}_{3} \mathrm{Nb}\right)$. Skład chemiczny materiału podłoża został przedstawiony w tablicy II.

Tablica II. Skład chemiczny stopu Hastelloy X, \% wag. [15] Table II. Chemical composition of Hastelloy X, wt. \% [15]

\begin{tabular}{|c|c|c|c|c|c|c|c|c|}
\hline $\mathbf{N i}$ & Cr & Fe & Mo & Co & W & C & Mn & Si \\
\hline 47 & 22 & 18 & 9 & 1,5 & 0,6 & 0,1 & 1 & 1 \\
\hline
\end{tabular}

Do identyfikacji faz w strefie granicznej wykorzystano metodę dyfrakcji rentgenowskiej XRD (ang. X-ray diffraction). Analizę dyfrakcyjną obszaru strefy granicznej wykonano po usunięciu strefy wielofazowej i fazy podstawowej (szlifowanie, polerowanie i trawienie). Obserwacje przygotowywanej próbki wykonywano za pomocą mikroskopu świetlnego Nikon Eclipse LV150.

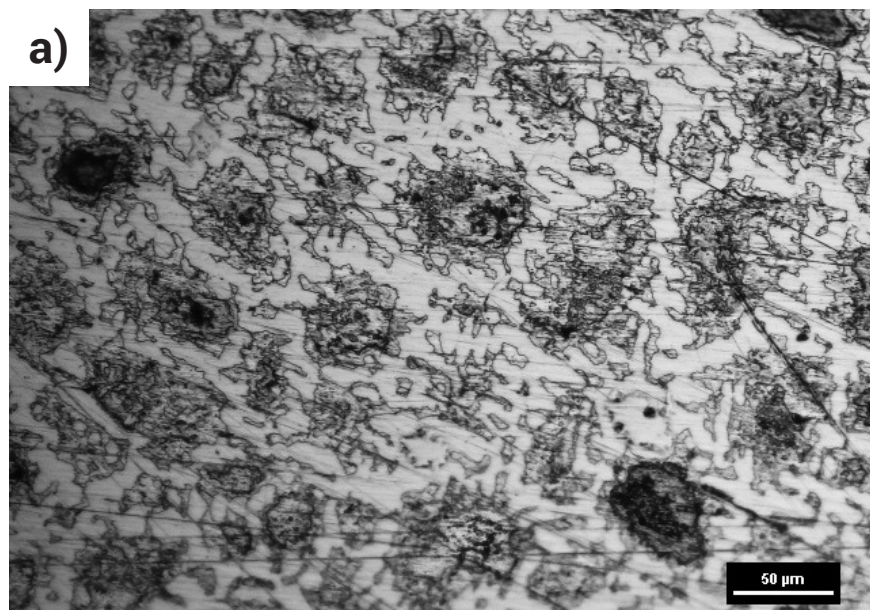

Analizę fazową przeprowadzono za pomocą dyfraktometru rentgenowskiego D8 DISCOVER Serii 2 firmy Bruker AXS, który jest wyposażony w lampę miedzianą. Parametry pomiaru były następujące: napięcie - $40 \mathrm{kV}$, prąd - $30 \mathrm{~mA}$, zakres kątowy $2 \Theta$ - od 10 do 120 , krok $\Delta 2 \Theta-0,025$, czas zliczania - $5 \mathrm{~s}$

W ramach identyfikacji poszczególnych faz wykonano także pomiar składu chemicznego w strefie granicznej metodą EDS (ang. Energy Dispersive Spectroscopy). Zobrazowanie badanej strefy oraz pomiar składu chemicznego wykonano za pomocą skaningowego mikroskopu elektronowego HITACHI SU8000.

\section{Wyniki i ich dyskusja}

Różnice pomiędzy poszczególnymi strefami połączenia lutowanego po wypolerowaniu i wytrawieniu są wyraźnie widoczne. Mikrostrukturę strefy wielofazowej z licznymi wydzieleniami przedstawiono na rysunku 2a. Badania metodą XRD wykonano w strefie granicznej, której mikrostruktura została przedstawiona na rysunku $2 \mathrm{~b}$.

Dyfraktogram wykonany dla strefy granicznej przedstawiono na rysunku 3. Stwierdzono występowanie w badanej strefie następujących faz:

- molibden nikiel $\left(\mathrm{Mo}_{1,08} \mathrm{Ni}_{2,92}\right)$,

- tetrataenite NiFe,

- chrom nikiel (CrNi),

- borek chromu $\mathrm{Cr}_{5} \mathrm{~B}_{3}$.

Dodatkowo analiza zapisów dyfrakcyjnych wskazuje na możliwość występowania dwóch dodatkowych faz:

- Bor chrom nikiel $\mathrm{Cr}_{3} \mathrm{NiB}_{6}$,

- Molibden nikiel krzem Mo6 $\left(\mathrm{Ni}_{0,75} \mathrm{Si}_{0,25}\right)_{7}$.

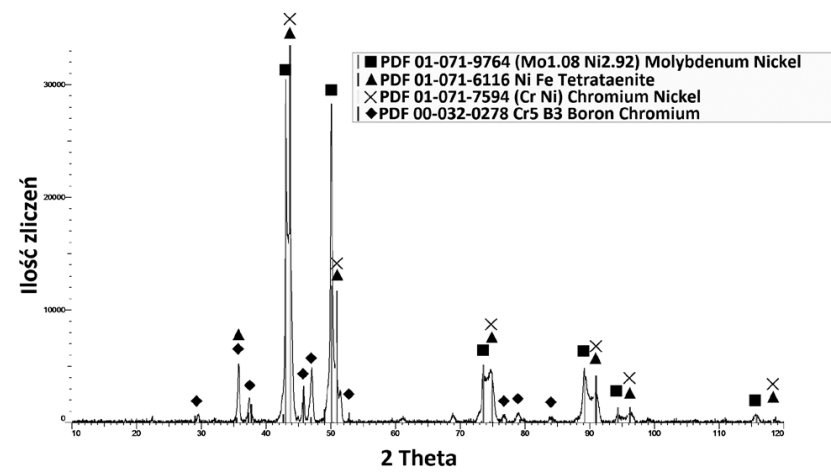

Rys. 3. Dyfraktogram dla strefy granicznej

Fig. 3. X-ray pattern for phase boundary zone

Rys. 2. Mikrostruktura połączenia lutowanego Hastelloy X - Palnicro 36M: a) strefa wielofazowa, b) strefa graniczna Fig. 2. Microstructure of Hastelloy $X$ - Palnicro $36 \mathrm{M}$ brazed joint: a) multiphase zone, b) phase boundary zone 
Obserwacje przy użyciu mikroskopu SEM ujawniły dwa rodzaje wydzieleń, które dzielą strefę graniczną na dwa różne obszary. Pierwsze $z$ nich są to drobne, ciemne wydzielenia (rys. 4a). Zlokalizowane są w badanej strefie w materiale, który uległ stopieniu podczas powstawania połączenia, a także we fragmentach ziaren stopu Hastelloy X bezpośrednio stykających się z fazą ciekłą.

Za pomocą SEM z wykorzystaniem techniki EDS określono skład chemiczny w punktach zaznaczonych na rysunku 4a. Pomiary wykonano w wydzieleniach oraz w osnowie. Dla porównania uzyskanych wyników analizy rentgenowskiej, obliczono udział masowy pierwiastków ze wzoru stechiometrycznego dla związku międzymetalicznego $\mathrm{Cr}_{3} \mathrm{NiB}_{6}$. Wyniki przedstawiono na rysunkach 4b i 4c oraz w tablicy III.

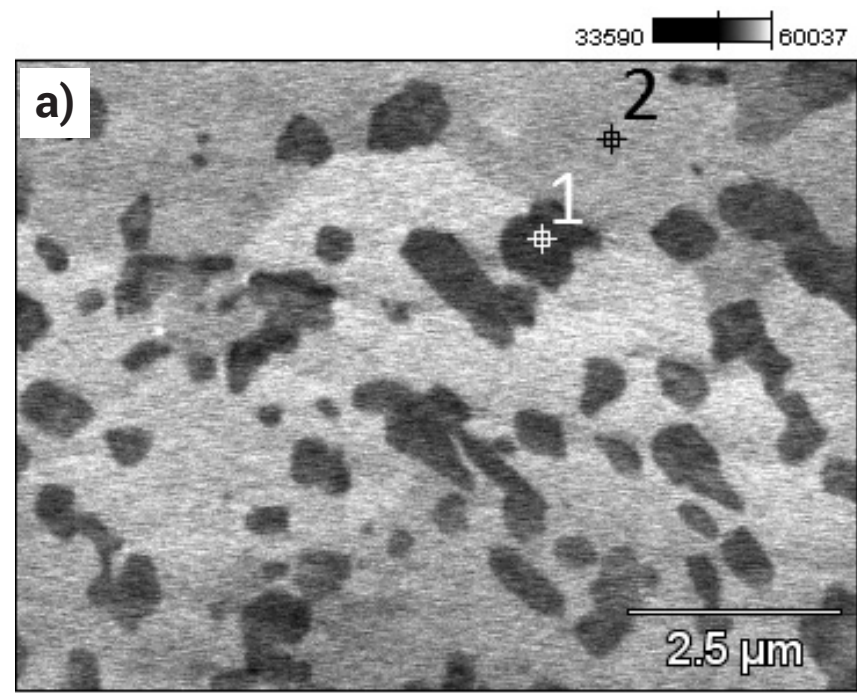

b)

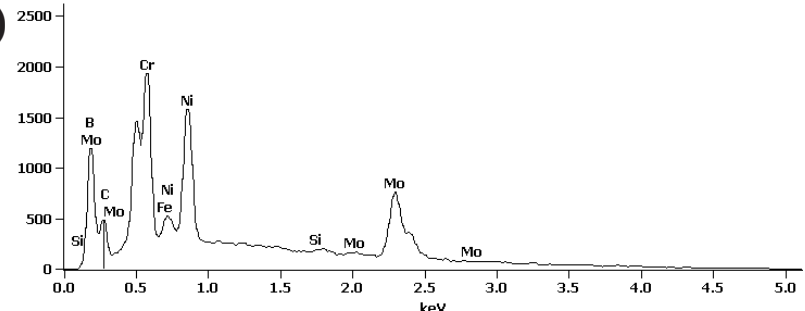

c)

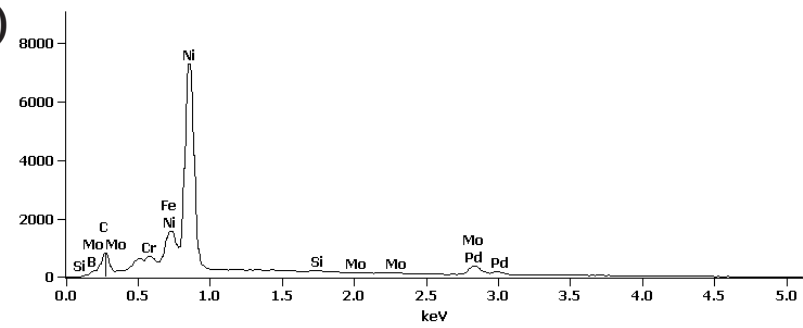

Rys. 4. Wyniki SEM EDS dla wydzieleń w strefie granicznej: a) obraz analizowanego obszaru - ciemne wydzielenia w lucie, b) pomiar EDS dla punktu 1, c) pomiar EDS dla punktu 2

Fig. 4. SEM EDS results for precipitations in phase boundary zone: a) image of the analyzed area - dark precipitations in brazing filler material, b) EDS measurement for point 1, c) EDS measurement for point 2
W ciemnych wydzieleniach zarejestrowano wzrost zawartości boru, chromu i molibdenu w porównaniu z osnową. Zawartość chromu w tych wydzieleniach jest bliska zawartości obliczonej dla związku międzymetalicznego $\mathrm{Cr}_{3} \mathrm{NiB}_{6}$. Wynik dla boru w wydzieleniach różni się z wartością obliczoną, jednakże pomiar dla tego pierwiastka metodą EDS obarczony jest dużym błędem dla badanego połączenia. Bor jest pierwiastkiem lekkim i w otoczeniu pierwiastków ciężkich jego pomiar jest ograniczony. Dodatkowo linia Ka dla boru pokrywa się z linią M dla molibdenu. Stwierdzenie występowania piku pochodzącego od boru wskazuje jedynie na jego obecność w badanym miejscu.

Spadek zawartości w ciemnych wydzieleniach w stosunku do osnowy zarejestrowano dla niklu i żelaza. Wartość jaką uzyskano dla niklu w wydzieleniach jest również mniejsza niż wartość obliczona dla związku międzymetalicznego $\mathrm{Cr}_{3} \mathrm{NiB}_{6}$, jednak różnica w porównaniu do osnowy jest znacznie mniejsza. W badanym obszarze ujawniono również inne pierwiastki m.in. Mo, $\mathrm{Fe}$ i Si.

Możliwość powstania fazy $\mathrm{Cr}_{3} \mathrm{NiB}_{6}$ podczas lutowania potwierdza trójskładnikowy układ równowagi fazowej Ni-Cr-B (rys. 5). W zakresie temperatury $800 \div 1000{ }^{\circ} \mathrm{C}, \mathrm{w}$ którym odbywa się proces technologiczny spajania, obserwuje się związek międzymetaliczny $\mathrm{Cr}_{3} \mathrm{NiB}_{6}[16]$.

Pomiar składu chemicznego metodą EDS pokazuje, że ciemne wydzielenia nie są związkiem międzymetalicznym $\mathrm{Cr}_{3} \mathrm{NiB}_{6}$. Uzyskane wyniki wskazują na obecność fazy bardziej złożonej, jednakże dopuszczają możliwość powstania innej fazy na bazie związku międzymetalicznego $\mathrm{Cr}_{3} \mathrm{NiB}_{6}$ wzbogaconej dodatkowymi pierwiastkami.

Przesuwając się dalej w głąb materiału rodzimego, zarejestrowano drugie z wydzieleń, które przedstawiono na rysunku 6a. Są to większe, jasne wydzielenia, znajdujące się w podłożu na granicy ziaren w obszarze strefy granicznej.

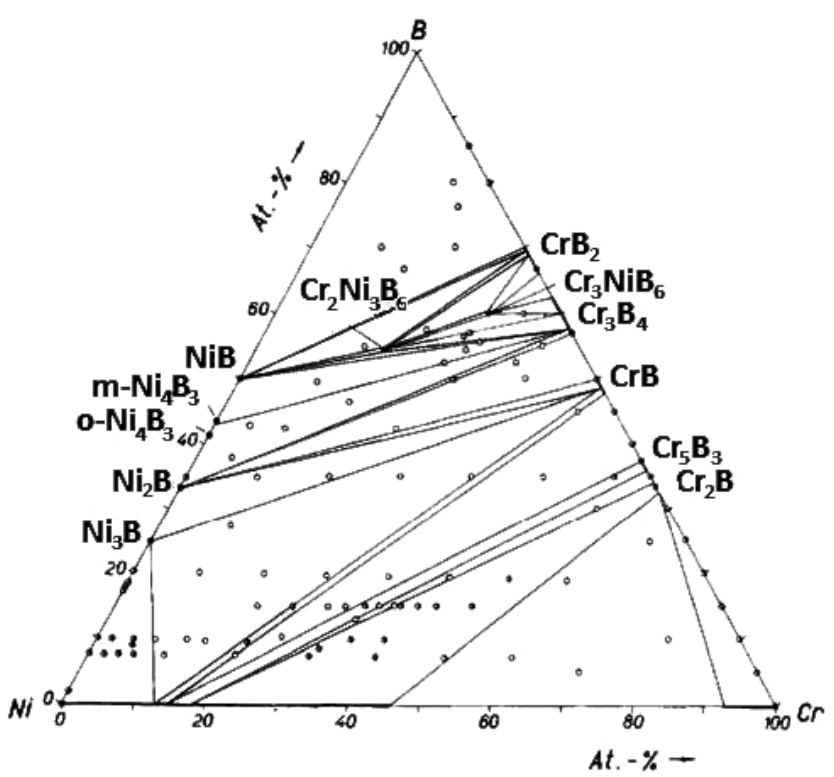

Rys. 5. Układ równowagi fazowej Ni-Cr-B w temperaturze $1000^{\circ} \mathrm{C}$ [16] Fig. 5. The ternary system Ni-Cr-B in temperature $1000^{\circ} \mathrm{C}[16]$

Tablica III. Skład chemiczny określonych punktów strefy granicznej (ciemne wydzielenia), \% wag.

Table III. Chemical composition of selected points of the phase boundary zone (dark precipitations), wt. \%

\begin{tabular}{|c|c|c|c|c|c|c|c|c|}
\hline & B-K & C-K & Si-K & Cr-L & Fe-L & Ni-L & Mo-L & Pd-L \\
\hline P-t 1 & 2,2 & 0,8 & 0,3 & 54,6 & 4,4 & 12,6 & 25,1 & - \\
\hline P-t 2 & 0,3 & 0,8 & 0,4 & 12,4 & 12,8 & 49,3 & 1,1 & 22,8 \\
\hline Cr $_{3}$ NiB $_{6}{ }^{* *}$ & 23 & - & - & 56 & - & 21 & - & - \\
\hline \\
* Skład procentowy masowy uzyskany z pomiaru metodą EDS \\
* Skład procentowy masowy obliczony ze wzoru stechiometrycznego \\
\hline
\end{tabular}


Tablica IV. Skład chemiczny określonych punktów strefy granicznej (jasne wydzielenia), \% wag.

Table IV. Chemical composition of selected points of the phase boundary zone (bright precipitations), wt. \%

\begin{tabular}{|c|c|c|c|c|c|c|c|}
\hline & B-K & C-K & Si-K & Cr-L & Fe-L & Ni-L & Mo-L \\
\hline P-t 1* & 0,0 & 1,4 & 2,5 & 15,9 & 8,4 & 23,2 & 48,6 \\
\hline P-t 2* & 0,0 & 0,6 & 0,5 & 21,9 & 20,0 & 49,4 & 7,6 \\
\hline Mo $_{6}\left(\mathrm{Ni}_{0,75} \mathbf{S i}_{0,25}\right)_{7}^{* *}$ & - & - & 5 & - & - & 33 & 62 \\
\hline $\begin{array}{l}\text { * Skład procentowy masowy uzyskany z pomiaru metodą EDS } \\
\text { * Skład procentowy maswy obliczony ze wzoru stechiometrycznego }\end{array}$ \\
\hline
\end{tabular}

Analogicznie jak w przypadku ciemnych wydzieleń wyznaczono skład chemiczny za pomocą SEM z wykorzystaniem techniki EDS, który porównano z udziałem masowym pierwiastków obliczonym ze wzoru stechiometrycznego

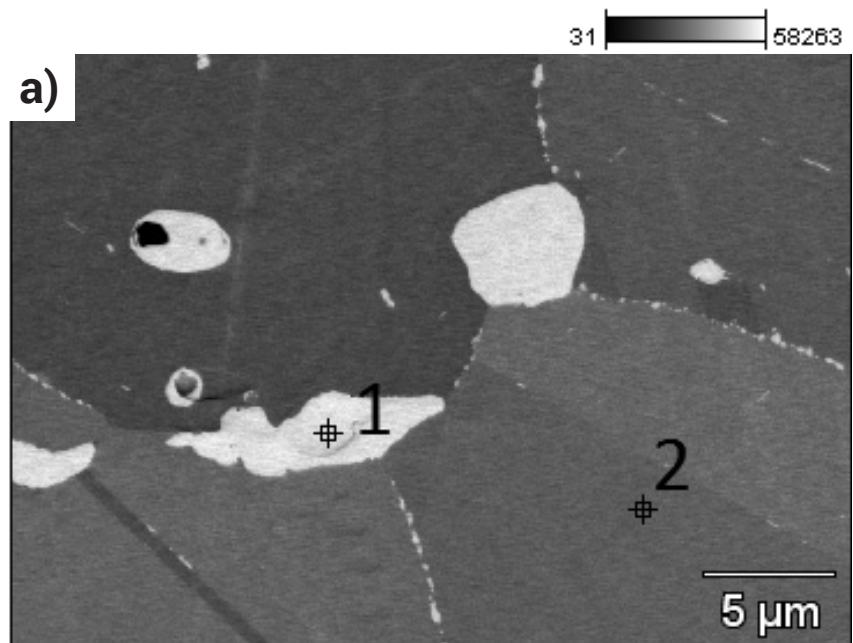

b) 3000

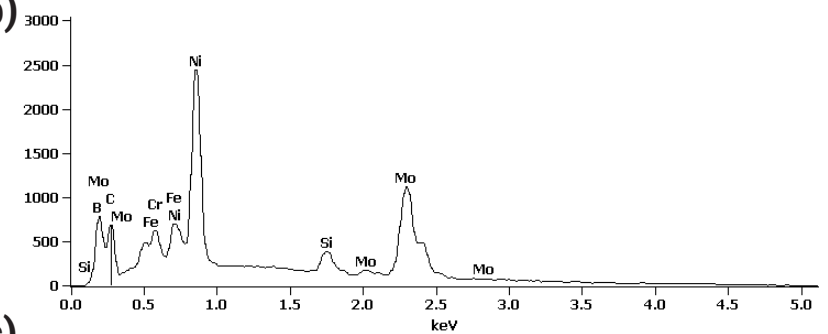

C)

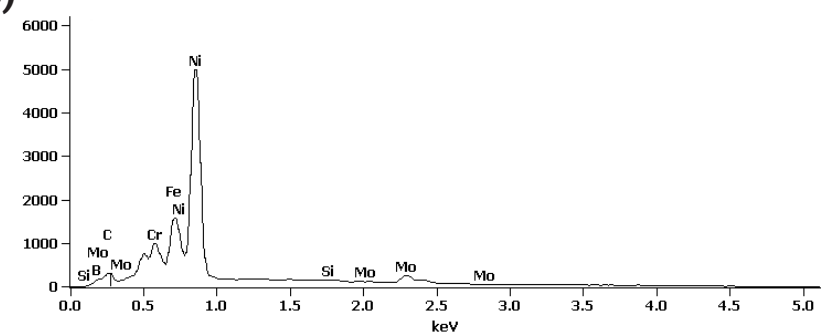

Rys. 6. Wyniki SEM EDS dla wydzieleń w strefie granicznej: a) obraz analizowanego obszaru - jasne wydzielenia w podłożu, b) pomiar EDS dla punktu 1, c) pomiar EDS dla punktu 2

Fig. 6. SEM EDS results for precipitations in phase boundary zone: a) image of the analyzed area - bright precipitations in base material, b) EDS measurement for point 1,c) EDS measurement for point 2 dla związku międzymetalicznego $\mathrm{Mo}_{6}\left(\mathrm{Ni}_{0,75} \mathrm{Si}_{0,25}\right)_{7}$. Wyniki pomiaru składu chemicznego przedstawiono na rysunkach $6 \mathrm{~b}$ i $6 \mathrm{c}$ oraz w tablicy IV.

W jasnych wydzieleniach w porównaniu z osnową zarejestrowano wzrost zawartości molibdenu i krzemu. Zmniejszyła się natomiast zawartość żelaza, chromu i niklu. W stosunku do zawartości Mo, Ni i Si obliczonych dla związku międzymetalicznego $\mathrm{Mo}_{6}\left(\mathrm{Ni}_{0,75} \mathrm{Si}_{0,25}\right)_{7} \mathrm{w}$ pomiarze EDS w miejscu wydzielenia stwierdzono mniejsze wartości dla tych pierwiastków. W jasnych wydzieleniach zarejestrowano również C, Cr i Fe.

Analiza literaturowa wskazuje na podobieństwo jasnych wydzieleń do fazy $\mathrm{Mo}_{6}\left(\mathrm{Ni}_{0,75} \mathrm{Si}_{0,25}\right)_{7}$ ujawnionej w stopie IC6 (Ni-Al-Mo-B), którą przedstawiono na rysunku 7 . W stopie IC6 wzbogaconym o $0,10 \div 0,20 \%$ Si i 0,12\% Y pojawiły się jasne wydzielenia w obszarze międzydendrytycznym. Analiza TEM wykazała, że jest to $\mathrm{Mo}_{6}\left(\mathrm{Ni}_{0,75} \mathrm{Si}_{0,25}\right)_{7}[17]$.

Ze względu na bardziej złożony skład chemiczny jasnych wydzieleń stwierdza się, że nie są one związkiem międzymetalicznym $\mathrm{Mo}_{6}\left(\mathrm{Ni}_{0,75} \mathrm{Si}_{0,25}\right)_{7}$. Jednak analiza literaturowa oraz stosunkowo nieduża różnica w składzie chemicznym nie wyklucza występowania fazy na bazie $\mathrm{Mo}_{6}\left(\mathrm{Ni}_{0,75} \mathrm{Si}_{0,25}\right)_{7}$ wzbogaconej o dodatki C, Cr i Fe.

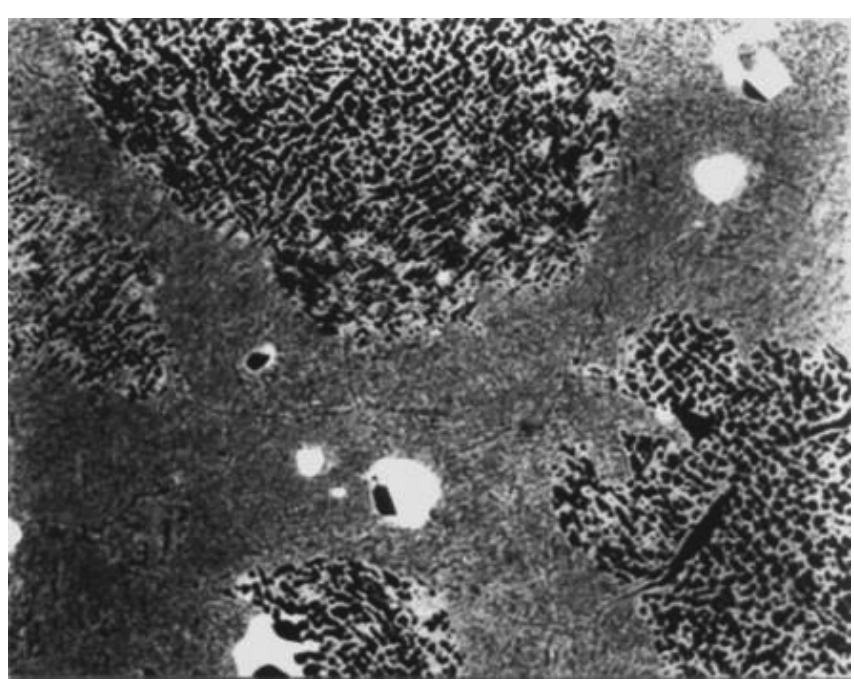

Rys. 7. $\mathrm{Mo}_{6}\left(\mathrm{Ni}_{0,75} \mathrm{Si}_{0,25}\right)_{7} \mathrm{~W}$ stopie IC6 z dodatkiem $0,10 \div 0,20 \% \mathrm{Si}$ i $0,12 \%$ Y [17]

Fig. 7. $\mathrm{Mo}_{6}\left(\mathrm{Ni}_{0.75} \mathrm{Si}_{0.25}\right)_{7}$ in alloy IC6 with addition of $0.10 \div 0.20 \mathrm{wt} \% \mathrm{Si}$ and $0.12 \mathrm{wt} \% \mathrm{Y}$ [17]

\section{Podsumowanie}

W ramach niniejszej pracy scharakteryzowano strefę graniczną połączenia Hastelloy X - Palnicro 36M. W badanym obszarze ujawniono dwa rodzaje wydzieleń powstałych w osnowie obejmującej obszar podłoża w stanie stałym i ciekłego lutu. Uzyskano złożony skład fazowy dla strefy granicznej połączenia Hastelloy X - Palnicro 36M.

Analiza dyfrakcyjna umożliwiła zidentyfikowanie w strefie granicznej faz utworzonych przez: molibden nikiel $\left(\mathrm{Mo}_{1,08} \mathrm{Ni}_{2,92}\right)$, tetrataenite NiFe, chrom nikiel (CrNi), bor chrom $\mathrm{Cr}_{5} \mathrm{~B}_{3}$. Wyniki uzyskane metodami XRD oraz EDS wskazały również na możliwość występowania w strefie granicznej faz na bazie związków międzymetalicznych $\mathrm{Cr}_{3} \mathrm{NiB}_{6} \mathrm{i} \mathrm{Mo}_{6}\left(\mathrm{Ni}_{0,75} \mathrm{Si}_{0,25}\right)_{7}$. 


\section{Literatura}

[1] Babul T., Jakubowski J., Kopeć J., et al: Lutowanie próżniowe uszczelnień ulowych w aparatach kierujących wykonanych ze stopów Hastelloy i Inconel z zastosowaniem lutu NiCrSiB, Przegląd Spawalnictwa, R. 79, nr 9, 2007, s.124-129.

[2] Dul I.: Zastosowanie i przetwarzanie stopów niklu w przemyśle lotniczym, Przegląd Spawalnictwa R. 81, nr 7-8, 2009, s. 67-73.

[3] Dul I., Kopeć J., Poradka A., et al: Wpływ wybranych czynników technologicznych na proces lutowania próżniowego stopów Ni i stali wysokostopowej 18-8, Przegląd Spawalnictwa R. 81, nr 10, 2009, s. 77-80.

[4] Dul I., Jakubowski J., Senkara J.: Spajanie zaawansowanych stopów Ni w przemyśle lotniczym, Rudy i Metale Nieżelazne, 2011, s. 397-405.

[5] Baranowski M., Jakubowski J.: Lutowność wybranych nadstopów niklu, Przegląd Spawalnictwa R. 86, nr 7, 2014, s. 3-8.

[6] Eng R.D., Ryan E.J., Doyle J.R.: Nickel-base brazing filler metals for aircraft gas turbine application, Weld J, Miami; United States, 1977, 56:10.

[7] Schwartz M.M.: Brazing, 2nd Editio, ASM International, Materials Park Ohio, 2003

[8] Sulzer Metco Braze Materials Guide, 2011.

[9] Palnicro Data Sheet, 2013, http://www.morganbrazealloys.com/media/ 1586/wesgo_metals_palniro_36m.pdf. Accessed 19 Oct 2017.

[10] Bober M., Jakubowski J., Senkara J.: Badania zdolności kapilarnych lutu BNi2 metodą zmiennej szczeliny lutowniczej, Przegląd Spawalnictwa, R. 88, nr 9, 2016, s. 87-90, doi: 10.26628/PS.V88I9.663.
[11] Edelmann F.: Characterization of the behavior of Palnicro brazing alloy for stainless steel joints, McGill University, 2005.

[12] Turner D.: Évolution microstructurale des joints brasés sur l'inconel 718 avecles alliages BNi-2 et PALNICRO, École de technologie supérieure, 2005.

[13] Rokvam M.: Caractérisation De Microstructures De Joints Brasés Avec Les Alliages Bcu-1, Bag-13a, Bau-4, Bau-6, Bni-1a, Bni-2, Bni-3 Et Palnicro 36M Ayant Pour Métal De Base Un Superalliage Base Nickel, École de technologie supérieure, 2011.

[14] Dul I., Senkara J., Bober M., Jakubowski J.: Wpływ wysokotemperaturowego wygrzewania próżniowego na lutowność Inconelu 718 lutem Palnicro 36, Przegląd Spawalnictwa R. 85, nr 9, 2013, s. 15-19.

[15] Hastelloy X Composition, 2017, http://www.espimetals.com/index.php/ technical-data/82-Hastelloy X Composition, Accessed 19 Oct 2017.

[16] Lugscheider E., Knotek O., Reimann H.: Das Dreistoffsystem NickelChrom-Bor, Monatshefte für Chemie 105 s. 80-90, 1974, doi: 10.1007/ BF00911291

[17] Xiao C.B., Han Y.F.: Effect of silicon on microstructure and stress rupture properties at $1100^{\circ} \mathrm{C}$ of yttrium modified Ni-Al-Mo-B alloy IC6, Journal of Materials Science vol. 36, 2001, pp.1027-1030, doi: 10.1023/A:1004848528582 